\title{
Nutraceuticals in Different Varieties of Cowpeas
}

\author{
Olabanji I.O. ${ }^{1, *}$, Ajayi O.S. ${ }^{1}$, Oluyemi E.A. ${ }^{1}$, Olawuni I.J. ${ }^{2}$, Adeniji A.O ${ }^{1}$, Olasupo O.F. ${ }^{1}$, \\ Agboola R.O. ${ }^{1}$, Olusesi I.M. ${ }^{1}$ \\ ${ }^{1}$ Department of Chemistry, Obafemi Awolowo University Ile-Ife, Nigeria \\ ${ }^{2}$ Department of Biochemistry and Molecular Biology, Obafemi Awolowo University, Ile-Ife, Nigeria \\ *Corresponding author: ioolabanji@yahoo.com, ioolabanji@oauife.edu.ng
}

\begin{abstract}
Eight varieties which comprise of three indigenous cowpeas \{Vigna vexillata (otili), Stenocarpa stylosa (feregede), and Phaseolus vulgaris (kokondo)\} Glycine max (soya beans), and the four new hybrids of Vigna unguiculata (big white, small white, drum, and honey beans) were analyzed for proximate, elemental, methyl fatty acid, total flavonoids, total phenolic contents and anti-oxidant contents. AOCA standard method was used for proximate analysis, the methanolic extracts of the cowpea were analysed for fatty acid and fatty acid methyl ester composition by Gas Chromatography- Flame Ionization Detector (GC-FID). The Ferric Ion Reducing Antioxidant Power (FRAP), Total Antioxidant Content (TAC) and 2,2- diphenyl-1-picrylhydrazyl (DPPH) free radical scavenging assays were used to measure the antioxidant activities of the samples. Total Flavonoid Content (TFC) and Total Phenolic Content (TPC) were also determined. The result shows that sample A has a balance proportion of food chemical composition and sample $\mathrm{H}$ (Phaseolus vulgaris) is richest in $\mathrm{Na}, \mathrm{Zn}, \mathrm{Mg}, \mathrm{Mn}$ while sample $\mathrm{D}$ (Big white cowpeas) is the richest in $\mathrm{Cu}$. The result of fatty acids shows sample A (soya beans) as the richest in the essential fatty acids $C_{18: 3 n 6} Y$-LinolenicAcid(1.66\%), $C_{18: 3 n 3} \alpha$-Linolenic Acid (4.86\%), $C_{22: 2}$ cis-13, 16-Docosadienoic Acid(5.84\%) (omega 3 and 6 fatty acids), while the indigenous Cowpeas were rich in the healthy monosaturated Fatty acids in an appreciable percentage and the commonest saturated fatty acids in plants (Palmitic and Stearic fatty acids only). Only sample $\mathrm{E}$ has essential fatty acids out of the four hybrids.
\end{abstract}

Keywords: cowpeas, hybrids, proximate analysis, anti-oxidants

Cite This Article: Olabanji I.O., Ajayi O.S., Oluyemi E.A., Olawuni I.J., Adeniji A.O, Olasupo O.F., Agboola R.O., and Olusesi I.M., "Nutraceuticals in Different Varieties of Cowpeas." American Journal of Food Science and Technology, vol. 6, no. 2 (2018): 68-75. doi: 10.12691/ajfst-6-2-2.

\section{Introduction}

Cowpea (Vigna unguiculata) is a crop which plays a significant role in the diet of Nigerians [1]. It is one of the cultivated species of genus Vigna. Africa is the largest country producing cowpea, particularly in Nigeria and Niger which account for $66 \%$ of world cowpea production [2-7]. Cowpea grain and leaves are edible products, cheap and are rich sources of protein. The seed provide important vitamins, phyto-nutrients including antioxidants besides carbohydrates, minerals and trace elements. It is an important source of food for humans, and the leaves can also be used as feed for livestock $[7,8]$. Cowpea adapts to a wide range of soils, and can survive in sandy (more than $85 \%$ sand and with less than $0.2 \%$ organic matter and low levels of phosphorus), clay and acid soils (pH 6) where other food legumes do not perform well, and this support the presence of nitrogen fixing bacteria and good drainage $[7,9]$. It is a shade tolerant plant, thus can be planted with other crops such as maize and millet in a subsistence farming system $[8,9]$.

Chemical composition of the cowpea seeds corresponds with that of most edible legumes showed that mature seeds contain per 100 g edible portion: carbohydrate 56-66 g, protein 22-24 g, water $11 \mathrm{~g}$, crude fibre 5.9-7.3 g, ash
3.4-3.9 g, fat 1.3-1.5 g, phosphorus $0.146 \mathrm{~g}$, calcium 0.104-0.076 g and iron $0.005 \mathrm{~g}$. Cowpeas also contain significant quantities of polyphenolic compounds such as simple phenols, flavonoids, and tannins, which could act as inflammatory modulators [10].

Cowpea has a lot of health benefits; it is used medicinally by grinding the seed, mixed with oil to treat boils [11]. The seed enhances the excretion of both sodium and chloride in the urine (diuretic). The liquor from the cooked seeds with spices is a potential remedy for the common cold [11]. When cooked and eaten as a food, it destroys worm in the stomach [12]. The leaves can be used as a snuff to treat headaches and can be applied on burns [13]. Its mineral contents are higher than that of meat, fish and egg $[14,15,16,17]$ which makes them useful in blood cholesterol reduction [18].

Antioxidants are an important part of the defense system of the human body, and help to withstand the oxidative stress caused by reactive oxygen species $[19,20]$. It is not really easy to measure the antioxidant activity but rather, the effects of the antioxidant in controlling the extent of oxidation. Natural antioxidants are good for human health because of decreasing heart disease risks and possessing anti-carcinogenic properties. They are also safer compared to synthetic antioxidants. Reports have showed that fatty acids possess antioxidant activity, anti-inflammatory activities and anticancer activity [21]. 
Fatty acids are organic acids that have two functional groups, an acid group at one end of its molecule, and methyl group at the other end; they are classified in omega groups 3, 6 and 9 [22]. According to the position of their first double bond, Omega 7 group are less important in human health. Fatty acid chains differ by length. Short-chain fatty acids (SCFA) are fatty acids with aliphatic tails of fewer than six carbons (e.g. butyric acid) [22]. Medium-chain fatty acids (MCFA) are fatty acids with aliphatic tails of 6-12 carbons, which can form triglycerides. Long-chain fatty acids (LCFA) are fatty acids with aliphatic tails 13 to 21 carbons [23]. Very long chain fatty acids (VLCFA) are fatty acids with aliphatic tails longer than 22 carbons.

There are two essential fatty acids (EFAs) for humans; alpha-linolenic acid [an omega-3 fatty acid (ALA)] and linoleic acid [an omega-6 fatty acid, (LA)] because they cannot be synthesized by the body and must be obtained from diet or supplementation [24]. Essential fatty acids are useful in the formation of healthy cell membrane, the proper functioning and the development of the brain and nervous system. It also helps in the production of hormone-like substances called eicosanoids (thromboxanes, leukotrienes, prostaglandins); which are responsible for the regulation of numerous body functions including blood pressure, blood viscosity, vasoconstriction, immune and inflammatory responses [25].

Some other fatty acids are sometimes classified as conditionally essential (they can become essential under some developmental or disease conditions) examples include (an omega-3 fatty acid) docosahexaenoic acid and gamma-linolenic acid (an omega-6 fatty acid).

Omega-3 fatty acid (Alpha-linolenic acid) is an essential fatty acid because it plays an important role in brain function, protecting against fatal heart disease and helps fight against cardiovascular disease.

The aim of this study is to carry out the proximate analysis of some hybrids of cowpeas, the indigenous cowpeas that are almost going into extinction and that of soya beans, determine the fatty acid composition of their methanolic extract and carry out the anti-oxidant properties of the cowpeas extracts.

\section{Materials and Methods}

\subsection{Sample Collection and Preparation}

Samples were obtained from local vendors at the main market (Oja tuntun) in Ile-Ife, Osun State, Nigeria. Bean pods, broken and damaged seeds, stones, bean stalks, and other foreign materials were removed manually through handpicking and fanning. They were sun - dried for three days to aid easy grinding. Each sample was ground to fine powder separately with the aid of an electrical grinding machine.

\subsection{Proximate Composition of Flours}

Carbohydrate, protein, fat, crude fibre and moisture content were determined by methods of AOAC [26]. Determinates were done in duplicates at the Department of Chemistry, Faculty of Science and Department of Animal
Science, Poultry Meat Research Laboratory, Faculty of Agriculture, Obafemi Awolowo University, Ile-Ife, Nigeria.

\subsection{Liquid Extraction}

$20 \mathrm{~g}$ of each ground sample was weighed into a soxhlet thimble and extracted with $300 \mathrm{~mL}$ of methanol $\left(40-60^{\circ} \mathrm{C}\right.$ ) according to the method of Horowitz [27] and Omoti and Okyi [28]. The solvent was concentrated and allowed drying in the fume hood to get the oil.

\subsection{Preparation of Fatty Acid}

The extracted oil was converted to fatty acid methyl esters (FAME) using potassium method. About $10 \mathrm{~mL}$ of the oil sample was dissolved with $1 \mathrm{ml}$ of n-hexane in a 2 $\mathrm{mL}$ test tube followed by addition the of $3 \mathrm{~mL}$ of $2 \mathrm{~N}$ $\mathrm{KOH}$ in methanol. The test-tube was closed and the sample was missed using a votex mixer for 1minute, it was opened and $2 \mathrm{~mL}$ of n-hexane was added, the resulting solution was put in $60 \square \mathrm{C}$ of water for 15 minutes and centrifuged for 20 minutes after which it the solution gavwo layers. The top layer (organic layer) which is the hexane layer was put in the auto-sampler and analyzed with GC-FID (Agilent GC-7890A) machine.

\subsection{Anti-Oxidant Activities}

\subsubsection{Determination of Total Phenol Content}

The total phenol content was determined by method of Singleton and Rossi [29] as described by Ren-You Gan et al. [30] using the folin-ciocalteu's phenol reagent which is an oxidizing reagent. $0.1 \mathrm{ml}$ of sample was diluted to $1 \mathrm{ml}$ with distilled water followed by addition of $0.2 \mathrm{ml}$ of folin-ciocalteu's phenol reagent and the resulting mixture voltexed. After 5 minutes of incubation, $1.0 \mathrm{ml}$ of $7 \%$ (w/v) $\mathrm{Na}_{2} \mathrm{CO}_{3}$ solution was added and the solution was diluted to $2.5 \mathrm{ml}$ followed by incubation for 90 minutes at room temperature. The absorbance against a control containing $0.1 \mathrm{ml}$ of water in place of the sample was taken at 750nm. A calibration curve of gallic acid was constructed and linearity was obtained in the range of 20$100 \mu \mathrm{g} / \mathrm{mL}$. The total phenolics content in the samples was expressed as mg of gallic acid equivalent (mg GAE/g extract) by using the standard curve. Distilled water was used as blank.

\subsubsection{Determination of Total Flavonoid Content}

This was carried out based on the aluminium chloride colorimetric assay method according to Chang et al. [31] as described by Pratapet al. [32]. $0.1 \mathrm{ml}$ of extract/standard was added to $0.4 \mathrm{ml}$ of distilled water. This was followed by $0.1 \mathrm{ml}$ of $5 \%$ sodium nitrite. After 5 minutes incubation, $0.1 \mathrm{ml}$ of $10 \%$ Aluminum Chloride and $0.2 \mathrm{ml}$ of $1 \mathrm{M}$ sodium hydroxide was added and the volume was made up to $2.5 \mathrm{ml}$ with distilled water. The absorbance at $510 \mathrm{~nm}$ was measured against the blank. A calibration curve of quercetin was constructed and linearity was obtained in the range of $0.2-1 \mathrm{mg} / \mathrm{mL}$. The total flavonoid content in samples was expressed as mg of quercetin equivalent (mg QUE/g extract). 


\subsubsection{DPPH Assay}

The radical scavenging ability of the oil was determined using the stable radical DPPH(2,2-diphenyl-1-picrylhydrazyl hydrate) as described by Braca et al. [33]. To $150 \mu \mathrm{L}$ of different concentrations of the samples or standard (vitamin C) in a test tube was added $150 \mu \mathrm{L}$ of $0.3 \mathrm{mM}$ $\mathrm{DPPH}$ in methanol. The mixture was mixed and incubated in the dark for 30mins after which the absorbance was read at $517 \mathrm{~nm}$ against a DPPH control containing only $150 \mu \mathrm{L}$ methanol in place of the extract.

The percent of inhibition was calculated in following way:

$$
\mathrm{I} \%=\left[\left(\mathrm{A}_{\text {blank }}-\mathrm{A}_{\text {sample }}\right) / \mathrm{A}_{\text {blank }}\right] \times 100
$$

Where $A_{\text {blank }}$ is the absorbance of the control reaction (containing all reagents except the test compound), and $\mathrm{A}_{\text {sample }}$ is the absorbance of the test compound. Sample concentration providing $50 \%$ inhibition $\left(\mathrm{IC}_{50}\right)$ was calculated from the graph plotting inhibition percentage against extract concentration.

\subsubsection{Determination of Total Antioxidant Capacity}

This method is based on the reduction of Molybdenum (VI) to Molybdenum (V) by the extract and the subsequent formation of a green phosphate/Molybdenum (V) complex at an acidic $\mathrm{pH}$ according to the method of Pellegrini et al. [34] as described by Bamidele et al. [35]. Briefly, $0.1 \mathrm{ml}$ of the samples or standard solutions of ascorbic acid $(20,40,60,80,100 \mu \mathrm{g} / \mathrm{ml})$ was added to $1 \mathrm{ml}$ of the reagent solution which consisted of $0.6 \mathrm{M}$ sulphuric acid, 28mM sodium phosphate and $4 \mathrm{mM}$ ammonium molybdate. The reacting mixture was incubated in a water bath at $95^{\circ} \mathrm{C}$ for $90 \mathrm{mins}$. The mixture was allowed to cool to room temperature and the absorbance measured at $695 \mathrm{~nm}$ against a blank which consisted of the reacting mixture containing distilled water in place of the extract. The antioxidant activities of the extracts were expressed as an ascorbic acid equivalent per gram of sample(AAE/g).

\subsubsection{Determination of Ferric Reducing Antioxidant Power (FRAP)}

The FRAP assay uses antioxidants as reductants in a redox-linked colorimetric method with absorbance measured with a spectrophotometer [36]. The principle of this method is based on the reduction of a brown ferric-tripyridyltriazine complex to its blue ferrous coloured form owing to the action of electron donating in the presence of antioxidants.

\subsubsection{Procedure}

A 300mmol/L acetate buffer of $\mathrm{pH} 3.6,10 \mathrm{mmol} / \mathrm{L} \mathrm{2,} \mathrm{4,}$ 6-tri-(2-pyridyl)-1, 3, 5-triazine and 20mmol/L FeCl $3 \cdot 6 \mathrm{H}_{2} \mathrm{O}$ were mixed together in the ratio of 10:1:1 respectively, to give the working FRAP reagent. A $50 \mu$ l aliquot of the samples or standard solutions of ascorbic acid (20, 40, 60, $80,100 \mu \mathrm{g} / \mathrm{ml}$ ) was added to $1 \mathrm{ml}$ of FRAP reagent. Absorbance measurement was taken at 593nm exactly 10 minutes after mixing against reagent blank containing $50 \mu \mathrm{l}$ of distilled water and $1 \mathrm{ml}$ of FRAP reagent.

All measurements were taken at room temperature with samples protected from direct sunlight. The antioxidant activities of the extracts were expressed as an ascorbic acid equivalent per gram of sample (AAE/g).

\subsection{Data Analysis}

The data was analyzed using GraphPadInstat 3 . One-way analysis of variance (ANOVA) followed by Tukey's significant difference post-test was used to determine statistical significance in the comparisons of White (Big), Soya beans, Otili, Feregede, Oloyin,White (small), Drum and Kokondo. For all the data obtained, statistical significance was set at $\mathrm{p}<0.05$.

\section{Results and Discussions}

\subsection{Proximate Composition of Cowpeas}

Generally, the results of parameters range of proximate analysis of both indigenous and improved hybrids is as shown in Table 1a; \% Moisture 7.85-11.8.; \% Ash: 3.65-6.04; \% Crude Fibre:0.45-2.52; Ether Extract: 2.0219.55; Crude Protein: 16.19- 36.75; \% Carbohydrate (0.84- 67.49). This result was not too distant from those of Osunbitan [37] in which the proximate analysis of two improved hybrid of cowpeas were carried out. Famata et al [38] corroborated the result of the indigenous cowpeas in this study with the result of the crude protein, carbohydrates and crude fibre of the raw local cultivar (Banjaram Jambo) similar to that of sample C (feregede) and sample $\mathrm{H}$ (Kokondo) of this work.

Table 1a. Range of Proximate Composition of Cowpeas in $\mu \mathrm{g} / \mathrm{g}$

\begin{tabular}{|c|c|c|c|c|c|c|c|}
\hline Sample & $\begin{array}{l}\text { \% Moisture } \\
\text { Range }\end{array}$ & \%Ash Range & $\begin{array}{c}\text { \% Crude Fibre } \\
\text { Range }\end{array}$ & \% Fat Range & $\begin{array}{c}\% \text { Crude } \\
\text { Protein Range }\end{array}$ & $\begin{array}{c}\% \\
\text { Carbohydrate } \\
\text { Range }\end{array}$ & References \\
\hline Hybrids & 7.85-10.06 & $4.24-6.04$ & $0.45-1.48$ & $2.29-2.96$ & $18.38-21.88$ & 61.9-64.61 & This study \\
\hline Indigenous & $9.10-11.8$ & $3.65-4.02$ & $2.04-4.61$ & $2.02-2.43$ & $16.19-20.13$ & 63.9-67.49 & “' \\
\hline Soya beans & 8.87 & 3.99 & 2.52 & 19.55 & 36.75 & 30.84 & “' \\
\hline Hybrids & $11.34-11.58$ & $3.25-3.49$ & $2.65-2.90$ & $1.68-1.89$ & $20.30-20.70$ & $59.42-60.78$ & $\begin{array}{c}\text { Osunbitan,et al, } \\
2016\end{array}$ \\
\hline Local cultivar & $5.55-6.90$ & $1.95-3.92$ & $2.61-3.68$ & $1.05-2.1$ & $17.42-19.82$ & $66.92-68.1$ & Famata et al, 2013 \\
\hline
\end{tabular}

The proximate data analyses are expressed as the mean \pm the standard error of the mean. Table $1 \mathrm{~b}$ X-rayed the differences in the proximate analysis between the indigenous cowpeas and the hybrids. It was found that the hybrids were not better in terms of proximate analysis because the values appear within same bracket. However, 
the difficulties in cooking may make people prefer the hybrids, it takes lesser time to cook, thus conserving cooking energy. In terms of colour, the hybrids are more attractive. Soya beans appear to be better than the hybrids and the indigenous cowpeas in this study, in that, the \% composition of the fat, protein and carbohydrate present appeared in better proportion as balanced food than in other cowpeas. It is often used as alternative source of animal protein in developing countries for mothers that cannot afford animal proteins such as milk and eggs and thus preventing protein malnutrition, soya milk drinks often replaces animal milk. Sometimes, soya beans is used to fortify cereals for babies and toddlers and serves as weaning food for children among low income resource mothers and families $[39,40,41,42,43]$.

Table 1b. Proximate composition of Cowpeas in $\mu \mathrm{g} / \mathrm{g}$

\begin{tabular}{|c|c|c|c|c|c|c|c|c|}
\hline Sample & Local Name & Botanical Name & \% Moisture & $\%$ Ash & $\begin{array}{c}\text { \% Crude } \\
\text { Fibre } \\
\end{array}$ & $\%$ Fat & $\begin{array}{c}\text { \% Crude } \\
\text { Protein } \\
\end{array}$ & Carbohydrate \\
\hline A & Soya Beans & Glycine max & $8.87 \pm 0.10^{\mathrm{b}, \mathrm{c}}$ & $3.99 \pm 0.05^{\mathrm{b}, \mathrm{c}, \mathrm{d}, \mathrm{f}, \mathrm{g}, \mathrm{h}}$ & $2.52 \pm 0.01^{\mathrm{b}, \mathrm{d}, \mathrm{h}}$ & $19.55 \pm 2.01^{\mathrm{b}}$ & $36.75 \pm 2.16^{\mathrm{b}}$ & $30.84 \pm 0.01^{\mathrm{b}}$ \\
\hline B & Otili & Vignavexillata & $9.10 \pm 0.09^{c}$ & $4.57 \pm 0.9^{\mathrm{c,d}, \mathrm{e}, \mathrm{f}, \mathrm{g}, \mathrm{h}}$ & $4.61 \pm 0.01^{\mathrm{c}}$ & $2.21 \pm 0.02^{\mathrm{c}, \mathrm{d}, \mathrm{e}, \mathrm{f}, \mathrm{g}, \mathrm{h}}$ & $20.13 \pm 0.01^{\text {ce, f,g }}$ & $\underset{h}{63.97 \pm 0.02^{c, f, g},}$ \\
\hline $\mathrm{C}$ & Feregede & Stenocarpastylosa & $\underset{\mathrm{g}}{10.24 \pm 0.20^{\mathrm{d}, \mathrm{f}}}$ & $3.65 \pm 0.04^{\mathrm{d}, \mathrm{f}, \mathrm{g}, \mathrm{h}}$ & $2.28 \pm 0.03^{\mathrm{d}, \mathrm{h}}$ & $2.43 \pm 0.04^{\mathrm{d}, \mathrm{e}, \mathrm{f}, \mathrm{g}, \mathrm{h}}$ & $16.19 \pm 0.22^{\mathrm{d}, \mathrm{g}, \mathrm{h}}$ & $67.49 \pm 0.99^{\mathrm{d}}$ \\
\hline D & White(Big) & Vignaunguiculata & $7.85 \pm 0.11^{\mathrm{a}}$ & $\begin{array}{c}4.24 \pm \\
0.14^{\mathrm{a}, \mathrm{b}, \mathrm{c}, \mathrm{d}, \mathrm{f}, \mathrm{g}, \mathrm{g}, \mathrm{h}}\end{array}$ & $0.45 \pm 0.01^{\mathrm{a}, \mathrm{e}, \mathrm{g}}$ & $\begin{array}{c}2.49 \pm \\
0.02^{\mathrm{a}, \mathrm{c}, \mathrm{d}, \mathrm{e}, \mathrm{f}, \mathrm{g}, \mathrm{h}, \mathrm{h}}\end{array}$ & $21.88 \pm 1.24^{\mathrm{a}, \mathrm{c}, \mathrm{e}, \mathrm{f}}$ & $\underset{f}{63.54 \pm 0.35^{a, c, e},}$ \\
\hline $\mathrm{E}$ & $\begin{array}{l}\text { Oloyin(Honey } \\
\text { Beans) }\end{array}$ & Vignaunguiculata & $9.74 \pm 0.05^{\mathrm{e}}$ & $6.04 \pm 1.12^{\mathrm{e}, \mathrm{g}}$ & $0.94 \pm 0.20^{\mathrm{e}, \mathrm{f}, \mathrm{g}}$ & $2.30 \pm 0.03^{\mathrm{e}, \mathrm{f}, \mathrm{g}, \mathrm{h}}$ & $20.13 \pm 0.62^{\mathrm{e}, \mathrm{f}, \mathrm{g}}$ & $61.79 \pm 0.14^{\mathrm{e}}$ \\
\hline $\mathrm{F}$ & White(Small) & Vignaunguiculata & $10.04 \pm 0.08^{\mathrm{f}, \mathrm{g}}$ & $4.22 \pm 0.06^{\mathrm{f}, \mathrm{g}, \mathrm{h}}$ & $1.48 \pm 0.23^{\mathrm{f}, \mathrm{g}}$ & $2.29 \pm 0.00^{\mathrm{f}, \mathrm{g}, \mathrm{h}}$ & $19.69 \pm 0.27^{\mathrm{f}, \mathrm{g}}$ & $63.76 \pm 0.23^{\mathrm{f}, \mathrm{g}, \mathrm{h}}$ \\
\hline G & Drum & Vignaunguiculata & $10.06 \pm 0.02^{\mathrm{g}}$ & $4.39 \pm 0.82^{\mathrm{g}, \mathrm{h}}$ & $0.95 \pm 0.44^{\mathrm{g}}$ & $2.56 \pm 0.02^{\mathrm{g}, \mathrm{h}}$ & $18.38 \pm 0.25^{\mathrm{g}, \mathrm{h}}$ & $64.61 \pm 0.81^{\mathrm{g}, \mathrm{h}}$ \\
\hline $\mathrm{H}$ & Kokondo & $\begin{array}{l}\text { Phaseolus } \\
\text { vulgaris }\end{array}$ & $11.8 \pm 0.10^{\mathrm{h}}$ & $4.02 \pm 0.02^{\mathrm{h}}$ & $2.04 \pm 0.12^{\mathrm{h}}$ & $2.02 \pm 0.00^{\mathrm{h}}$ & $17.06 \pm 0.03^{\mathrm{h}}$ & $65.02 \pm 1.01^{\mathrm{h}}$ \\
\hline
\end{tabular}

Values were compared along each column. Values carrying different superscripts in each column are significantly different (p $<0.05$ ).

\subsection{Mineral Contents of Cowpeas in $(\mu \mathrm{g} / \mathrm{g})$}

The mineral elements appear in these order and ranges Na: $\mathrm{H}>\mathrm{A}>\mathrm{G}>\mathrm{C}>\mathrm{D}>\mathrm{E}>\mathrm{F}>\mathrm{B}$ (11.28-551.48) $\mu \mathrm{g} / \mathrm{g}$; Zn: $\mathrm{H}>\mathrm{E}>\mathrm{D}>\mathrm{C}>\mathrm{G}>\mathrm{A}>\mathrm{F}>\mathrm{B}(2.33-23.73) \mu \mathrm{g} / \mathrm{g}$; Cu: $\mathrm{D}>\mathrm{C}>\mathrm{E}>\mathrm{H}>\mathrm{F}>\mathrm{B}>\mathrm{G}>\mathrm{A}(5.85-25.38) \mu \mathrm{g} / \mathrm{g}$; Mg: $\mathrm{H}>\mathrm{G}>\mathrm{E}>\mathrm{C}>\mathrm{A}>\mathrm{D}>\mathrm{F}>\mathrm{B}(60.50-192.35) \mu \mathrm{g} / \mathrm{g}$; Mn: $\mathrm{H}>\mathrm{D}>\mathrm{C}>\mathrm{A}>\mathrm{G}>\mathrm{F}>\mathrm{E}>\mathrm{B}(9.18-22.62) \mu \mathrm{g} / \mathrm{g}$. The result shows that sample $\mathrm{H}$ (Phaseolus vulgaris) is richest in $\mathrm{Na}, \mathrm{Zn}, \mathrm{Mg}, \mathrm{Mn}$ while sample D (Big white cowpeas) is the richest in $\mathrm{Cu}$. Farmers should be encouraged to propagate the production of Phaseolus vulgaris which is almost going to extinction because of the rich mineral composition. Considering the composition of soya beans and the essential elements in Phaseolus vulgaris the two cowpeas should be considered for food/weaning formulation of growing children, especially in the developing world for low income families. However, the results of the essential elements analyzed in this study compared with those analyzed by Famata et al [38] were different, $\mathrm{Na}$ in Banjaram and Kananado (raw) were 50 and $37 \mathrm{mg} / \mathrm{kg}$ respectively. In this study, the results of $\mathrm{Na}$ in the cowpeas were higher except in sample B (otili - 11.28 $\mu \mathrm{g} / \mathrm{g}$ ), Zn was low in all the indigenous samples $(\mathrm{B}, \mathrm{C}, \mathrm{H})$ of this study than those analyzed by Famata et al [38] except in $\mathrm{H}$ (kokondo) while $\mathrm{Mg}$ was higher in the indigenous cowpeas than those of Famata et al. [38]. The differences in the mineral composition depend on many factors including concentration levels of elements in the soil, translocation rates of the elements by the cultivars from the soil, and instrumental detection limits during analysis [44]. Cowpea, like other plants derived the minerals needed for structural growth and catalytic functions from the mother soil, thus, its mineral composition depend on how rich the soil is [45]. All these essential elements are important for proper bone and teeth formation (Mg), body electrolytes $(\mathrm{Na})$, maintain tissues homeostasis $[46,47]$ and other functions for brain development and prevention of certain diseases.

Table 2. Mineral Contents of Cowpeas in $(\mu \mathrm{g} / \mathrm{g})$

\begin{tabular}{|c|c|c|c|c|c|c|c|c|}
\hline Mineral & A & B & C & D & E & F & G & H \\
\hline Sodium & $354.25 \pm 0.02$ & $11.28 \pm 0.01$ & $119.90 \pm 0.01$ & $98.95 \pm 0.00$ & $93.4 \pm 0.01$ & $20.58 \pm 0.01$ & $114.98 \pm 0.01$ & $551.48 \pm 0.00$ \\
\hline Zinc & $3.25 \pm 0.00$ & $2.33 \pm 0.02$ & $3.28 \pm 0.02$ & $3.60 \pm 0.02$ & $4.13 \pm 0.01$ & $2.65 \pm 0.00$ & $3.23 \pm 0.01$ & $23.73 \pm 0.01$ \\
\hline Copper & $5.85 \pm 0.01$ & $13.78 \pm 0.01$ & $19.20 \pm 0.01$ & $25.38 \pm 0.00$ & $18.00 \pm 0.00$ & $17.23 \pm 0.00$ & $6.58 \pm 0.01$ & $17.75 \pm 0.00$ \\
\hline Magnessium & $84.48 \pm 0.01$ & $60.5 \pm 0.01$ & $89.75 \pm 0.01$ & $84.13 \pm 0.02$ & $113.65 \pm 0.01$ & $62.38 \pm 0.00$ & $132.95 \pm 0.01$ & $192.35 \pm 0.01$ \\
\hline Manganese & $15.43 \pm 0.00$ & $9.18 \pm 0.00$ & $19.50 \pm 0.01$ & $20.13 \pm 0.00$ & $10.13 \pm 0.00$ & $13.93 \pm 0.01$ & $15.4 \pm 0.00$ & $22.62 \pm 0.02$ \\
\hline
\end{tabular}

\subsection{Fatty Acid Composition of the Cowpeas}

From Table 3, sample A contains the two essential fatty acids (EFAs); omega 3 fatty acid $\alpha$-Linolenic Acid (4.86\%) and cis-13,16-Docosadienoic Acid (5.84\%) and $Y$-Linolenic Acid (1.66\%). However the presence of high percentage of Linolelaidic Acid (17.83\%) is undesirable because of its role in the cause of sudden cardiac death. Linolelaidic acid as methyl ester could find its usefulness in biodiesel. Sample $\mathrm{C}, \mathrm{E}$ and $\mathrm{H}$ also contain essential fatty acids; $\mathrm{C}_{22: 2}$ cis-13,16-Docosadienoic acid $(6.63 \%) \omega-3, \mathrm{C}_{18: 2}$ Linoleic acid (12.86\%) $\omega-6$ and $\mathrm{C}_{22: 6 n 3}-4,7,10,13,16$, 19-Docosahexaenoic Acid (40.7\%) $\omega$-3. EFAs cannot be synthesized by the body; sample A, C, E and H could be a 
good source to the body [48]. The presence of linoleic acid $(\omega-6)$ and $\alpha$-linolenic acid ( $\omega-3)$, make them useful in skin care formulations as they restrict the formation of eczemas. These EFAs are able to incorporate into the lipid components of cell membranes and to regenerate damaged lipid barrier of epidermis and restrict the loss of water. Unsaturated fatty acids show pronounced healing effects and are thus used as anti-skin inflammation and in skin care products [49].

Table 3. Percentage Fatty Acids Composition of the Cowpeas

\begin{tabular}{|c|c|c|c|}
\hline Sample & SFA( \% RA) & MUFA(\%RA) & PUFA (\%RA) \\
\hline A & $\begin{array}{c}\mathrm{C}_{16: 0} \text { palmitic acid }(5.67 \%), \mathrm{C}_{18: 0} \text { stearic } \\
\text { acid(1.23\%) } \\
\text { TOTAL }=6.90 \%\end{array}$ & $\begin{array}{c}\mathrm{C}_{16: 1} \text { palmitoleicacid(1.18\%) } \\
\mathrm{C}_{17: 1} \text { Heptadecanoic acid(54.83\%) } \\
\mathrm{C}_{18: 1 \mathrm{n} 9 \mathrm{t}} \text { ElaidicAcid(6.91\%) } \\
\text { TOTAL }=62.92 \%\end{array}$ & $\begin{array}{c}\mathrm{C}_{18: 2 \mathrm{n} 6 \mathrm{t}} \text { Linolelaidic Acid(17.83\%), } \\
\mathrm{C}_{18: 3 \mathrm{n} 6} \mathrm{Y} \text {-LinolenicAcid(1.66\%), } \\
\mathrm{C}_{18: 3 \mathrm{n} 3} \alpha \text {-Linolenic Acid (4.86\%), } \\
\mathrm{C}_{22: 2} \text { cis-13,16-Docosadienoic Acid(5.84\%) } \\
\text { TOTAL = 30.19\% }\end{array}$ \\
\hline B & $\begin{array}{c}\mathrm{C}_{16: 0} \text { Palmitic Acid }(13.75 \%) \\
\text { TOTAL }=13.75 \% \\
\end{array}$ & $\begin{array}{c}\text { C }_{17: 1} \text { Cis-10-Heptadecanoic Acid (58.26\%) } \\
\text { C }_{18: 1 \text { n9t Elaidic Acid(3.23\%) }} \\
\text { TOTAL }=61.49 \% \\
\end{array}$ & $\begin{array}{c}\mathrm{C}_{18: 2 \mathrm{n} 9 \mathrm{t}} \text { Linolelaidic Acid(24.75\%) } \\
\text { TOTAL }=24.75 \% \\
\end{array}$ \\
\hline $\mathrm{C}$ & $\begin{array}{c}\mathrm{C}_{16: 0} \text { Palmitic Acid (2.06\%) } \\
\text { Total }=2.06 \%\end{array}$ & $\begin{array}{c}\text { C }_{17: 1} \text { Cis-10-Heptadecanoic Acid }(91.30 \%) \text {, } \\
\text { TOTAL }=91.30 \%\end{array}$ & $\begin{array}{c}\mathrm{C}_{22: 2} \text { cis-13,16-Docosadienoic Acid }(6.63 \%) \\
\text { TOTAL }=6.63 \%\end{array}$ \\
\hline $\mathrm{D}$ & ND & ND & ND \\
\hline $\mathrm{E}$ & $\begin{array}{c}\mathrm{C}_{16: 0} \text { Palmitic acid }(32.79 \%) \\
\mathrm{C}_{11: 0} \text { Cyclopropane caprylic acid } \\
(7.50 \%) \\
\mathrm{C}_{18: 0} \text { Stearic acid }(10.10 \%) \\
\text { TOTAL: } 50.39 \%\end{array}$ & $\begin{array}{l}\mathrm{C}_{16: 1} \text { Palmitoleic acid (25.48\%) } \\
\text { TOTAL: } \quad 25.48 \%\end{array}$ & $\begin{array}{l}\mathrm{C}_{18: 2} \text { Linoleic acid } \\
\text { TOTAL: }\end{array}$ \\
\hline $\mathrm{F}$ & $\begin{array}{c}\mathrm{C}_{16: 0} \text { Palmitic acid }(17.13 \%) \\
\mathrm{C}_{18: 0} \text { Stearic acid }(13.38 \%) \\
\mathrm{C}_{11: 0} \text { undecylic acid }(3.41 \%) \\
\text { TOTAL:33.92\% }\end{array}$ & $\begin{array}{c}\mathrm{C}_{18: 1} \text { Cis-vaccenic acid (35.9\%) } \\
\text { TOTAL: } 35.9 \%\end{array}$ & ND \\
\hline G & $\begin{array}{c}\mathrm{C}_{6: 0} \text { isocaproic acid }(0.36 \%) \\
\mathrm{C}_{18: 0} \text { Stearic acid }(3.05 \%) \\
\text { TOTAL: } 3.41 \% \\
\end{array}$ & ND & ND \\
\hline $\mathrm{H}$ & ND & $\begin{array}{c}\mathrm{C}_{15: 1} \text { cis-10-Pentadecanoic Acid }(3.318 \%) \\
\mathrm{C}_{22: 1 \mathrm{n} 9} \text { Erucic Acid (55.9\%) } \\
\text { TOTAL }=59.218\end{array}$ & 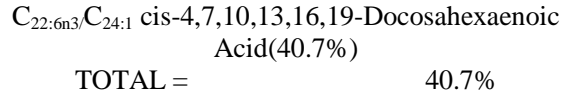 \\
\hline
\end{tabular}

ND - Not Detected.

However, the highest percentages of the fatty acids found in these cowpeas are monounsaturated Fatty acids (MUFAs). They are healthy type of fat, these have been found to be healthy and beneficial to the body, because they are found in excess in majority of these cowpeas, especially the indigenous type-samples A,B,C and H. The roles of these monounsaturated fatty acids may likely override the effects of less healthy fats, such as saturated fats and trans fats, thus the synergetic effects of monounsaturated fatty acids, the poly unsaturated fatty acids, especially EFAs will make the oil of cowpeas more desirable.

Many researchers found MUFAs effective in reducing the risk of certain diseases; American Heart Association AHA [50] stated that MUFA help lower the risk of heart disease by lowering the cholesterol levels. For instance, MUFAs may lower the total and low-density lipoprotein (LDL) cholesterol levels but maintain high-density lipoprotein (HDL) cholesterol level. It may also help improve the function of the blood vessels, thus reduces the incidence of stroke. Mark Wolk et al [51] concluded that MUFAs decreases the risk of breast cancer, feeding on diet rich in MUFAs can help in reducing belly fat [52]. Diet rich in MUFAs plays vital role in improving the pain and stiffness of those who already have rheumatoid arthritis. Sample C has $91.30 \%$ of $\mathrm{C}_{17: 1}$ Cis-10-Heptadecanoic Acid, amidst samples A (54.83\%) and B (58.26\%), this FA had been known with possible anti-tumor properties [53], and antimicrobial agent that destroys fungi by suppressing their ability to grow or reproduce [54]. Sample C was found among other samples in this study as a main source of $\mathrm{C}_{17: 1}$ Cis-10-Heptadecanoic Acid. $\mathrm{C}_{22: 1 \mathrm{n} 9}$ Erucic Acid and $\mathrm{C}_{18: 1 \mathrm{n} 9 \mathrm{t}}$ Elaidic Acid are $\omega-9$ series FAs that help in reducing the trans-epidermal water loss, so improve the skin moistening, activate regeneration of damaged lipid barrier of the epidermis, heal inflammations and stabilize the skin metabolism [55]

Saturated Fatty Acids (SFAs) generally exhibit appreciable solubility in water when compared with their corresponding hydrocarbons because of the presence of the carbonyl group - $\mathrm{COO}^{-}$. They are soluble in organic solvents particularly in chloroform and least soluble in acetonitrile, this is of importance in their use in industries. The short chain FAs have been found to facilitate weight control when included in the diet as a replacement for long-chain triglycerides [56]. The commonest SFAs in this study are palmitic and stearic acids; these have found their usefulness in detergent formulations, shampoo and lubricants. In nutrients, SFAs have been found healthy in consumption in that meta-analysis of prospective epidemiologic studies showed that there is no significant evidence for concluding that dietary saturated fat is associated with an increased risk of cardio-vascular diseases (CVD). More data are needed to elucidate whether CVD risks are likely to be influenced by the specific nutrients used to replace saturated fat [57].

Generally, some SFAs, MUFAs and PUFAs(EFAs) are good for dietary purposes, so also many FAs are useful in cosmetics industries base of creams and active ingredients in formulations of emulsions, cosmetic milks and masks, ointments, hair conditioners, protective lipstick, bath fluids, nail varnish and nail cleaners [58,59]. 
Table 4. Results of Total Antioxidant Activity (TAA), DPPH Free Radical Scavenging Activity and Ferric reducing Antioxidant Power (FRAP) of the methanolic extract of the Cowpea species

\begin{tabular}{cccccc}
\hline SAMPLE & $\begin{array}{c}\text { LOCAL } \\
\text { NAME }\end{array}$ & BOTANICAL NAME & $\begin{array}{c}\text { Total Antioxidant } \\
\text { Capacity }(\mathrm{mg} \\
\text { AAE/g) }\end{array}$ & $\begin{array}{c}\text { DPPH Free Radical } \\
\text { Scavenging Activity IC } 50 \\
(\mathrm{mg} / \mathrm{mL})\end{array}$ & $\begin{array}{c}\text { FRAP } \\
(\mathrm{mg} \text { AAE/g) }\end{array}$ \\
\hline A & Soya Beans & Glycine max & $17.10 \pm 0.58$ & $1.787 \pm .09$ & $9.30 \pm 0.74$ \\
B & Wild Cowpea Otili & Vigna vexillata & $11.98 \pm 0.9$ & $1.24 \pm 0.05$ & $4.76 \pm 0.17$ \\
C & Feregede & Stenocarpa stylosa & $13.33 \pm 0.25$ & $4.27 \pm 0.53$ & $2.38 \pm 0.32$ \\
D & White (Big) & Vigna unguiculata & $1052.89 \pm 116.92$ & $5.71 \pm 0.23$ & $0.54 \pm 0.04$ \\
E & Oloyin (Honey beans) & Vigna unguiculata & $2797.8 \pm 878.86$ & $1.70 \pm 0.02$ & $29.41 \pm 2.86$ \\
F & White (Small) & Vigna unguiculata & $2342.41 \pm 80.80$ & $0.75 \pm 0.02$ & $2.46 \pm 0.38$ \\
G & Drum & Vigna unguiculata & $2655.40 \pm 356.46$ & $2.05 \pm 0.08$ & $33.41 \pm 3.19$ \\
H & Kokondo & Phaseolus vulgaris & $4.62 \pm 0.10$ & $7.18 \pm 0.18$ & $2.87 \pm 0.32$ \\
\hline
\end{tabular}

\subsection{Antioxidant Activity}

The antioxidant activity of the cowpea samples were determined using DPPH (2, 2-diphenyl-1-picrylhydrazyl) free radical scavenging, TAC (Total antioxidant capacity) and FRAP (Ferric Reducing Antioxidant Power) assays (Table 4). DPPH free radical scavenging ability was determined through the hydrogen donation mechanism. The scavenging ability of all samples was moderately different in the various varieties of samples analyzed. DPPH scavenging abilities were usually expressed as $\mathrm{IC}_{50}$ value which measures the concentration that will inhibit $50 \%$ or half of the scavenging process. The cowpea sample Vigna unguiculata (white small) has the lowest concentration to inhibit 50\% ( IC $_{50} 0.75 \pm 0.02 \mathrm{mg} / \mathrm{mL}$ ) when compared to Vigna unguiculata (white big) and Phaseolus vulgaris (kokondo) with $\mathrm{IC}_{50}$ value of $5.71 \pm$ 0.23 and $7.18 \pm 0.18 \mathrm{mg} / \mathrm{mL}$ respectively. The antioxidant activity measured by FRAP ranged from $33.41 \pm 3.19$ $0.54 \pm 0.04 \mathrm{mg} \mathrm{AAE} / / \mathrm{g}$ sample. The cowpea variety Vigna unguiculata (Drum) demonstrated the highest value, followed by Vigna unguiculata (Oloyin). The trend of antioxidant activity as observed by FRAP assay was similar to those observed by DPPH IC 50 . The result obtained as shown in table showed that the four new hybrids of Vigna unguiculata (big white, small white, drum, and honey beans) contained higher antioxidant compounds as revealed by the TPC and TFC than the other varieties and this agreed with similar results obtained by Zia-Ul-Haq et al. [60]. The total antioxidant activity (TAC) was also generally higher as observed for all four new coloured hybrids of Vigna unguiculata. It can be concluded that coloured hybrids of Vigna unguiculata exhibited better total antioxidant activity than others, this result is in agreement with similar work previously reported [61,62]. Antioxidant activity of each cowpea variety is different due to antioxidant assay used which are sensitive to different antioxidant compounds in them [63].

\subsection{Total Phenolic and Flavonoid Contents}

The total phenolic content (TPC) and total flavonoids content (TFC) of the eight varieties of cowpea samples were $4.06 \pm 9.73-1218.46 \pm 34.97 \mathrm{mg}$ gallic acid equivalent/g sample and $8.46 \pm 2.22-792.69 \pm 45.43$ mg quercetin equivalent/g sample, respectively (Table 5). In all the varieties of the cowpeas, the phytochemical contents such as the phenolic and flavonoid contents of the samples vary. The cowpea sample of Vigna unguiculata (white small) has the highest content of TPC while Phaseolus vulgaris (kokondo) has the least. The cowpea variety Vigna unguiculata (Oloyin) has the highest concentration of flavonoid content (TFC) while in the same manner as Phaseolus vulgaris (kokondo) has the least.

Table 5. Results of Total Phenolic (TPC) and Total Flavonoid Content (TFC) of the methanolic extract of the Cowpea species

\begin{tabular}{ccccc}
\hline SAMPLE & LOCAL NAME & BOTANICAL NAME & $\begin{array}{c}\text { Total Phenolic Content (TPC) } \\
(\mathrm{mg} \text { GAE/g) }\end{array}$ & $\begin{array}{c}\text { Total Flavonoid Content (TFC) } \\
(\mathrm{mg} \text { QUE/g) }\end{array}$ \\
\hline A & Soya Beans & Glycine max & $39.50 \pm 1.96$ & $54.35 \pm 8.21$ \\
B & Wild Cowpea & Vignavexillata & $27.60 \pm 1.91$ & $23.10 \pm 10.71$ \\
C & Feregede & Stenocarpastylosa & $15.61 \pm 1.106$ & $24.69 \pm 1.85$ \\
D & White (Big) & Vignaunguiculata & $48.66 \pm 1.76$ & $274.99 \pm 41.31$ \\
E & Oloyin & Vignaunguiculata & $94.48 \pm 3.16$ & $792.69 \pm 45.43$ \\
F & White (Small) & Vignaunguiculata & $1218.46 \pm 34.97$ & $234.21 \pm 40.45$ \\
G & Drum & Vignaunguiculata & $453.44 \pm 9.09$ & $623.90 \pm 15.60$ \\
H & Kokondo & Phaseolus vulgaris & $4.06 \pm 9.73$ & $8.46 \pm 2.22$ \\
\hline
\end{tabular}

\section{Conclusion}

Considering the composition of soya beans and the essential elements in Phaseolus vulgaris, the two cowpeas should be considered for food /weaning formulation of growing children, especially in the developing world for low income families. Farmers should be encouraged to cultivate Phaseolus vulgaris which is almost going to extinction because of the rich mineral composition. The fatty acid composition of these cowpeas showed that, apart from being useful in supplying essential fatty acids, the indigenous cowpeas fatty acid will find usefulness in 
cosmetic industries. Their anti oxidants property will enhance healthy living by assisting in scavenging free radicals in the body. Thus both the indigenous and the hybrids are capable as nutrients supplier and enhancer of the proper functioning of the body system.

\section{References}

[1] Ape, D., Nwogu, N. A., Nwafor, E. C. and Umoren, C. N. (2015). Comparative Proximate and Elemental Analysis of Four Species of Cowpea Beans Seed Coat (Vigna Ungucuilata) in Enugu State Nigeria.Vol.4:2,pp 1-8.

[2] Ehlers, J. D. and Hall, A. E. (1997). Cowpea (Vigna unguiculata L. Walp.). Field Crops Resources, 53, 187-204.

[3] Akintunde, O. K., Akinremi, T. B. and Nwauwa, L. O. E. (2012). Food grain marketing in Osun State, Nigeria: a study of long-run price integration. Continental J. Agricultural Economics, 6 (1), $1-9$.

[4] FAO (2002). Word Agriculture : Towards 2015/2030 Summary report, Rome.

[5] Adaji, M. J., Olufala, O. O. and Aliyu, L. (2007). Effect of intrarow spacing and stand density on the growth and yield of cowpea (Vigna unguculata (L.) Walp). In: Olulaja, O. O., Omokore, D.F., Akpa, G. N. and Sanni, S. A. (eds.). Proceedings of the 41st Annual Conference of the Agricultural Society of Nigeria (ASN) held at the Institute for Agricultural Research, Samaru, Ahmadu Bello University, Zaria between 22nd and 26th October, 2007. Pp 153-157.

[6] Mula, MG and Saxena, KB. (2010). Lifting the Level of Awareness on Pigeonpea - A Global Perspective. Patancheru 502 324, Andhra Pradesh, India: International Crops Research Institute for the Semi-Arid Tropics. 540 pp. ISBN: 978-92-9066535-9.Order code: BOE 051.

[7] Singh, B.B., Mohan Raj, D.R., Dashiell, K.E. and Jackai L.E.N. (eds.). 1997. Advances in cowpea research. Co-publication of International Institute of Tropical Agriculture (UTA) and Japan International Research Center for Agricultural Sciences (JIRCAS). UTA, Ibadan, Nigeria. ISBN 978131110 X.

[8] Ayenlere, A.E., Mohammed, A.B., Duste, F., Abdullahi, M., and Mohammed -Lawal A., (2012). An assessment of economics of maize-cowpea cropping system in Ogum area of Kwara state. Nigeria biological and environmental sciences journal for the tropics .9(1): 39-43.

[9] Perrino, P., Laghetti, G., Spagnoletti Zeuli, P. L. and Monti, L.M. (1993). Diversification of cowpea in the Mediterranean and other centres of cultivation. Genetic resources and crop evolution, 40, $121-132$.

[10] Ukpene, A.O.1 and Imade, F.N. (2015). Amino Acid Profiles Of Seven Cowpea Varieties Grown In Agbor. Nigerian Annals of Natural Sciences, Volume 15 (1) 2015 (Pp 072-078).

[11] Duke, J.A. (1990). Introduction to food legumes. In: Insect Pests of Tropical Food Legumes, (Ed.): S.R. Singh. John Wiley and Sons, Chichester, UK.

[12] Chopra, R.N., Nayar, S.L. and Chopra. I.C. (1986). Glossary of Indian Medicinal Plants (Including the Supplement). Council of Scientific and Industrial Research, New Delhi.

[13] Hutchings, A., Scott, A.H., Lewis, G. and Cunningham, A.B. (1996). Zulu Medicinal Plants: An Inventory, University of Natal Press, Pietermaritzburg.

[14] Platt, B.S.(1962). Table representative value of foods commonly used in tropical countries .Med Res.Counc.especial. edition report series. No. 303 London.

[15] Adams, M. W. (1984). Cowpea production constraint and national programmes. Bean/Cowpea Collaboration Research Support Programme. Michigan State University, East Lansing. U.S. A.

[16] Rachie, K. O., Singh, S. R. and Rachie, S. K. (1985). Introduction to cowpea research, production and utilization. Bobliography: pp. 375-445.

[17] Achuba, F. I. (2006). The effect of subletethal concentration of crude oil on the growth and metabolism of cowpea (Vigna unguiculata) seedlings. The Environmentalist 21(1):17-20.

[18] Anderson, J.W. (1985). Cholesterol lowering effects of canned beans for hypercholesterolmic Medical. Clinical Resources 33(4):871-875.
[19] Ahmed Moussa, Aissat Saad and Djebli Noureddine (2012). How Honey Acts as an Antioxidant? Medicinal Aromatic Plants. 1:e121.

[20] Elisa, C. G., Albena Numes S. and Marta Rubinode de O.(2012). Oxidants, Antioxidants, and the Beneficial Roles of ExerciseInduced Production of Reactive Species. Oxidative Medicine and Cellular Longevity.Volume 2012 (2012), Article ID 756132, 12 pages.

[21] Mostafa, T.and Seidmahdi, J. (2015). Application and stability of natural antioxidants in edible oils in order to substitute synthetic. additives. J. Sci Technol. 52(3): 1272-1282.

[22] Cifuentes, Alejandro (ed.) (2013). "Microbial Metabolites in the Human Gut”. Foodomics: Advanced Mass Spectrometry in Modern Food Science and Nutrition. John Wiley and Sons.

[23] Beermann, C., Jelinek, J., Reinecker, T., Hauenschild, A., Boehm, G. and Klör, H.-U. (2003)."Short term effects of dietary mediumchain fatty acids and n-3 longchain polyunsaturated fatty acids on the fat metabolism of healthy volunteers”. Lipids in Health and Disease. 2: 10.

[24] Simopoulos, A. (2008). The importance of the omega-6/omega-3 fatty acid ratio in cardiovascular disease and other chronic diseases. Experimental Biology and Medicine. Published online 11, April 2008.

[25] Narinder, K., Vishal, C. and Anil, K. G. (2014). Essential fatty acids as functional components of foods- a review. J Food Sci Technol.; 51(10): 2289-2303.

[26] AOAC (2002). Official methods of analysis (16 $6^{\text {th }}$ ed.).Washington, DC,USA. Assoication Official Analysis Chemists.

[27] Horowitz, W. (1984). Method of Analsis of the Association of official Analytical Chemists. AOAC, washinton.

[28] Omoti, O. and P.A. Okyi, (1987). Characerization and Composition of the Pulp Oil and Cake of the African Pear: Dacryodes edulis. J. Sci. Food Agric. 38:67-70.

[29] Singleton, V. L. and Rossi, J. A. (1965). Colorimetry of Total Phenolics with Phosphomolybdicphosphotungstic acid reagents. Am. J. Enol. Vitic. 16, 144-158.

[30] Ren-You Gan1, Xiang-Rong Xu2, Feng-Lin Song1, Lei Kuang1 and Hua-Bin Li (2010). Antioxidant activity and total phenolic content of medicinal plants associated with prevention and treatment of cardiovascular and cerebrovascular diseases. Journal of Medicinal Plants Research. Vol. 4(22), pp. 2438-2444.

[31] Chang, C, Yang, M., Wen, H and Chern, J. (2002). Estimation of total flavonoid content in Propolis by two complementary colorimetric methods. Journal of Food and Drug Analysis 10(3): 178-182.

[32] Pratap, S. S., Seema, G., Neetu, P. and Nimisha, S.(2013).Surfactin: a review on novel microbial surfactant. Int. J. Bioassays 2, 740-745.

[33] Braca, A., Tommasi. N.D., Bari L.D., Pizza, C., Politi, M. And Morelli, I. (2001). Antioxidant principles from Bauhinia terapotensis. J. Nat. Prod. 64:892-895.

[34] Pellegrini, N., Serafini, M., Colombi, B., Del rio,, D., Salvatore, S., Bianchi, M. and Brighenti, F. (2003). Total antioxidant capacity of plant foods, beverages and oils consumed in Italy assessed by three different in vitro assays. J. Nutr. 133: 2812-2819.

[35] Bamidele Oluwaseun P., Mofoluwaso B. Fasogbon, Olalekan J. Adebowale and Adeyemi A. Adeyanju (2017). Effect of Blanching Time on Total Phenolic, Antioxidant Activities and Mineral Content of Selected Green Leafy Vegetables. 24(4): 1-8, 2017; Article no. CJAST.34808. Current Journal of Applied Science and Technology.

[36] Panda, B.N., Raj, A.B., Shrivastava, N.R., and Prathani, A.R. (2009). The evaluation of nitric oxide scavenging activity of Acalypha indica Linn Root. Asian Journal Research Chemistry, 2(2): 148-150.

[37] Osunbitan, S.O., Taiwo, K. A., Gbadamosi, S. O. and Fasoyiro, S. B.(2016).Essential mineral elements in flours from two improved varieties of cowpea. American Journal of Research Communication. Vol 4 (3).

[38] Famata, A.S., Modu, S. Mida, H.M., Hajjagana, L. Shettima, A.Y and Hadiza, A., 2013. Chemical composition and mineral element content of two cowpea varieties as food supplement. International Research Journal of Biochemistry and Bioinformatics 3 (4): 93-96.

[39] WHO (2000). Nutrition for health and development. A global agenda for combating malnutrition progress report, world health organization.

http://whqlibdoc.who.int.nq/2000/WHO_NHD_006.PDF. 
[40] Ilarotimi, O. S. and Famurewa, J.A.V. (2006). Assessment of chemical composition of soyabeans supplemented weaning foods and nutritional knowledge of nursing mothers on their utilization. Pak. J. Nutr., 5: 218-228.

[41] Okafor, J. N.C., Ozumba, A. U., Osibanjo, T., onu, L. I., Daodu, A. M. and Olatunji, O.O. (2008). Chemical microbial and sensory properties of wearing foods from blend of Nigeria food stuff . $J$. Ind. Res. Technol. 2: 31-36.

[42] Ugwu, F. M. (2009). The potential of roots and tuber as wearing foods. Pak. J. Nutri. 8:1701-1705.

[43] Inyang, C. U. and Offiong, E. E. (2010). Effect of storage temperature on microbial safety of ogi. Nig. Food. J. ,28: 85-92.

[44] Asante, K., Adu-Dapaah, H. and Acheampong A. O.(2007). Determination of Some Mineral Components of Cowpea (Vigna unguiculata (L.) Walp). Using Instrumental neutron activation analysis. Periodical: West Africa Journal of Applied Ecology. Vol.11. pp. 165-171.

[45] Purves, W. K., Orians, H. G. and Heller, C. H. (1992). Brain research bulletin. Life. pp. 679-682.

[46] Linder, M. C. (1991). Nutrition and metabolism of the major minerals. In Nutritional Biochemistry and Metabolism with Clinical Applications, 2nd edn. (M. C. Linder, ed.) Appleton and Lange, USA.

[47] Danso, K. E., Serfor-Armah, Y., Nyarko, B. J., Anim-Sampong, S. and Osae, E. K. (2001). Determination of some mineral components of cassava (ManihotesculentaCranz,) using instrumental neutron activation analysis. J.Radioanal. Nucl. Chem. 250(1): 139-142.

[48] Wang, H.X., Wu, H., Ho, C.T. and Weng, X.C. (2006). Cocoa butter equivalent from enzymatic interesterification of tea seed oil and fatty acid methyl esters. Food Chemistry, vol. 97, no. 4, pp. 661-665.

[49] Proksch, E., Brandner, J.M and Jensen, J.M. (2008): The skin: an indispensable barrier. Exp. Dermatol. 17, 1063-1072.

[50] American Heart Association (2017). Monounsaturated Fat; https://healthyforgood.heart.org/Eatsmart/Articles/Monounsaturated-Fats

[51] Mark Wolk, Alicia (1998): “A Prospective Study of Association of Monounsaturated Fat and Other Types of Fat With Risk of Breast Cancer,” Archives of Internal Medicine. http://archinte.ama-assn.org/cgi/content/abstract/158/1/41.

[52] Donaghue, K., M. M., Pena, A.K.F., Chan, B. L., Blades, J., King, L.H., Storlienand M. Silink (2000). "Beneficial effects of increasing monounsaturated fat intake in adolescents with type
1 diabetes”. Diabetes Research and Clinical Practice, 48(3): 193-199.

[53] Fukuzawa, M., Yamaguchi, R. and Hide, I. (2008). Possible involvement of long chain fatty acids in the spores of Ganodermalucidum (ReishiHoushi) to its anti-tumor activity. Biol Pharm Bull 31: 1933-7.

[54] Avis, T. J. and Bélanger, R. R. (2001). Specificity and mode of action of the antifungal fatty acid cis-9-heptadecenoic acid produced by Pseudozymaflocculosa. Applied and environmental microbiology .67, 956-960.

[55] Lamer-Zarawska E., Chwała C., GwardysA. (2012). Rośliny wkosmetycei kosmetologi iprzeciwstarzeniowej. Wydawnictwo Lekarskie PZWL, Warszawa.

[56] St-Onge, Marie-Pierre and Jones Peter H. (2002). Physiological effects of medium-chain triglycerides: potential agents in the prevention of obesity. J Nutr. 132 (3): 329-332.

[57] Dr. Mercola: Reasons to Eat More Saturated Fat. http://articles.mercola.com/sites/articles/archive/2009/09/22/7reasons-to-eat-more-saturated-fat.aspx. Retrieved 29/08/2017.

[58] Uauy, R. and Dangour, A. D. (2006): Nutrition in brain development and aging: role of essential fatty acids. Nutr. Rev. 64, 24-33.

[59] Bojarowicz, H. and Woźniak, B.(2008).Polyunsaturated fatty acids and their influence on skin condition. Probl. Hig. Epidemiol. 89, 471-475.

[60] Muhammad Zia-Ul-Haq1, Sanja Avar, Mughalqayum, Inamullah Khan, Shakeelahmad. (2013). Chemical composition and antioxidant potential of Acacia leucophloea Roxb. Acta Bot. Croat. 72 (1), 133-144.

[61] Maina, A. N., Yanou, N. N., Tchiagam, J. N., Richard, M. N. and Joseph, M. (2016). Genetics of seed flavonoid content and antioxidant activity in cowpea (Vigna unguiculata L). Walp. The Crop Journal; pp. 391-397.

[62] Dzomba, P., Togarepi, E. and Mupa, M.(2013). Anthocyanin content and antioxidant activities of common bean species (Phaseolus vulgaris L.) grown in Mashonaland Central, Zimbabwe. African Journal of Agricultural Research. Vol. 8(25), pp. 33303333, 4 July, 2013.

[63] Aguilar-Garcia, C., Gavino, G., Baragano-Mosqueda, M., Hevia, P., and Gavino, V. C. (2007). Correlation of tocopherol, tocotrienol, $\gamma$-oryzanol and total polyphenol content in rice bran with different antioxidant capacity assays. Food Chemistry, 102(4), 1228-1232. 